\title{
The influence of participatory assistance and organizational culture on strengthening social capital of Buddhist cooperative
}

\author{
Rahmad Setyoko ${ }^{*}$ \\ ${ }^{1}$ Dharmaduta, State Buddhist Collage of Raden Wijaya, Wonogiri, Indonesia
}

\section{ABSTRACT}

The social capital of an organization strengthens mutually beneficial cooperation to achieve common goals. This research aims to analyze the influence of participatory assistance and organizational culture on strengthening the Buddhist Cooperative's social capital. This research employs a quantitative approach with an ex post facto method. The sample was 77 members of Cooperative Maju Makmur Sampetan, and data were collected by using a questionnaire. Findings show that participatory assistance and organizational culture significantly influence strengthening the social capital of Buddhist Cooperative. Based on the regression analysis, it shows that there is a positive and significant influence of participatory assistance on social capital, which is equal to $44.5 \%$. Organizational culture also has a positive and significant influence on social capital, with a determination of $32.1 \%$. Furthermore, multiple regression analysis results show that both variables simultaneously influence strengthening social capital, with the coefficient of determination by $76.6 \%$. Thus, participatory assistance and organizational culture have a positive effect on strengthening social capital of Buddhist Cooperative.

\author{
ARTICLE INFO \\ Keywords: \\ participatory assistance; \\ organizational culture; \\ Buddhist Cooperative

\section{Article History:} \\ Received: April 4th 2021 \\ Revised: June 24th 2021 \\ Accepted: June 25th 2021 \\ Published: June 28 ${ }^{\text {th }}, 2021$ \\ How to Cite in APA Style: \\ Setyoko, R. (2021). The \\ influence of participatory \\ assistance and organizational \\ culture on strengthening \\ social capital of Buddhist \\ cooperative. Smaratungga: \\ Journal of Education and \\ Buddhist Studies, 1(1), 40-54.
}

\section{Introduction}

The background of this research is primarily to refer to economic development in Indonesia, especially in rural areas, to reach well-to-do society. Therefore, it needs to create a stable economy among the society, one of which is by conducting cooperative activities because it could generate positive social externalities, particularly in rural and developing areas (Tremblay et al, 2019). Cooperatives are more durable in times of economics stress (Boone, 2014). A cooperative is an autonomous association of persons united voluntarily to meet their everyday economic, social, and cultural needs and aspirations through a jointly owned and democratically controlled enterprise.

Cooperatives are kind of organizations which create as an association to fulfill the members' comment needs and as an institution configurated by government to improve the living standards of the low-income people (Hubaib, 2020). The principles of the cooperatives are open membership, democratic control, distribution of surplus in proportion to trade, payment of limited interest on capital, political and religious neutrality, cash trading and promotion of

\footnotetext{
*Corresponding author: rasyoka2019@gmail.com

Published by Center of Research and Publication of Smaratungga Buddhist College

This is an open access article under the CC BY-NC 4.0

(https://creativecommons.org/licenses/by-nc/4.0/)
} 
education (Thompson in Tremblay et al, 2019). Later on, according to the International Co-operation Alliance, it includes autonomy and independence, concern for community (2015).

A Buddhist cooperative has been established through Participatory Action Research (PAR) held by Smaratungga Buddhist College in 2017. It took place in Sampetan Village, Boyolali, Central Java that legally named Cooperative Maju Makmur Sampetan (MMS). MMS establishment aims to empower Buddhist people in overcoming various poverty problems related to basic facilities and infrastructure, human resource development, and economic development.

The community's ability to work together cannot be separated from the role of social capital they have. The nature of social capital is the social relationship that is interwoven in the daily lives of citizens. The core of social capital lies in how society's ability to work together to build a network in achieving common goals. Partono's research (2017) showed that Cooperative Maju Makmur Sampetan has very high category ( $86 \%)$ in applying social values and humanity as a basis for the development of social capital.

Social capital is a social and cultural aspect with economic value. It can be institutionalized, namely the overall resources, both actual and potential related to the ownership of a network of institutional relations that are fixed based on mutual recognition. Lawang (2004) revealed that social capital recognized three essential aspects: networks, norms, and social trust, which encourage social collaboration (coordination and cooperation) to achieve the common goal.

Karunatilake explained that the basis for development according to the Buddhist economic system is cooperation and business harmonization in people (Harvey, 2000). Schumacher states that Buddhist economics must be different from modern materialism economics since it sees civilization's essence, not only man's work (Harvey, 2010). Schumacher is aware of the principal difference between the Buddhist economy and the modern, materialistic economy. Buddhists see that the essence of civilization is to purify human character rather than increase the desire to achieve through work.

Marhalim's research (2015) revealed that strengthening social capital was directed from weak social capital towards high social capital. The condition of high social capital is indicated by cooperative having high norms, trust, and a good network. The social capital is strengthened by: increasing the social capital stock of the community, encouraging cooperative based on the principles of empowerment, developing clear rules in a participatory manner, conducting program evaluations in a participatory manner, strengthening capacity, enforcing procedures, advocating and building collaboration between cooperative and other partners.

The participatory approach is prevalent and has a rapid development in the past 20 years, especially in training to create and develop community capacity and empowerment. A participatory approach is essential to improve knowledge, skills, and attitude changes in a community with unique social, cultural, and economic conditions. The participation process is a skill that each person owns. However, this ability needs to be processed and communicated to create a participatory process, which builds confidence, builds a dialogue process, provides learning and skills that trainees can apply in the assistance process. The main characteristics of this training are: (1) the instructor/facilitator relationship with participants is no 
longer vertical but horizontal, (2) prioritizing the process rather than results, (3) the substance of the training material refers to the needs of participants.

Buddha has applied the method of educating adults (andragogy). Andragogy concerns learning through problems that have direct relevance to his personal life (problem-based learning). The Buddha applied this method when a woman asked him to revive his only child, who died (Sutanto, 2010). The Buddha did not refuse but agreed on one condition: to collect a handful of pepper from a family that had never experienced a family member's loss. The woman walked door to door and was unsuccessful. She realized that all creatures would be dead. Losing the loved one is suffering. The woman finally became a disciple of the Buddha and was known as Kisāgotamì.

Organizational culture is a pattern or system in the form of attitudes, values, behavioral norms, language, beliefs, and rituals formed, developed, and passed on to members of the organization as the organizational personality that can distinguish from others. Somba's research on the influence of organizational culture on social solidarity (2017) showed that organizational culture significantly affected social solidarity. Bernadeak's research (2016) showed that organizational culture influenced Organizational Citizenship Behavior (OCB).

Ogbonna and Harris define organizational culture as beliefs, values, meanings, and assumptions collectively shared by a social group to reinforce how they interact and reinforce them in responding to the environment (Sobirin, 2007). The organizational culture observed is behavior patterns which are manifestations or expressions of basic assumptions and values. O'Reilly, Chatman, and Caldwell put forward organizational culture characteristics: innovation and risk-taking; stability and security; respect for people; orientation of results; team orientation and collaboration; aggressiveness and competition.

Strengthening social capital is essential in forming a Buddhist cooperative. Efforts to strengthen social capital can be made through participatory assistance, which involves all members' participation in solving a problem. Previous studies indicate that organizational culture has a vital role in shaping the organization's character and quality. Researcher is interested in analyzing the influence of participatory assistance and organizational culture on strengthening the social capital of Buddhist Cooperative, especially Cooperative Maju Makmur Sampetan, Boyolali, Central Java.

\section{Method}

This study uses a quantitative approach with ex post facto research methods. Sukardi (2003) explains that ex post facto is research in which a series of independent variables have occurred when researchers begin to observe the dependent variable. The nature of ex post facto research is that there is no control over variables. Variables are seen as they are. in this study, researchers did not start the process from the beginning but immediately took the results. 


\section{Research object}

This study's object is Cooperative Maju Makmur Sampetan, located in Gumuk, Sampetan Village, Ampel District, Boyolali Regency. Cooperative Maju Makmur Sampetan has a legal institution called the Producer Cooperative Maju Makmur Sampetan, approved in the Decree of the Minister of Cooperatives and Small and Medium Enterprises Number: 008707/BH/M.KUKM.2/VI/2018.

\section{Population and sampling}

The population in this study were all members of Cooperative Maju Makmur Sampetan that amount to 77 people. The sample in this study is the entire population.

\section{Data collection procedure}

The methods used to collect data in this study are observation, documentation, and questionnaire. Observation and documentation methods are carried out to obtain qualitative and quantitative data relating to the object's description and characteristics. The questionnaire method is used to obtain quantitative data related to respondents' responses to research variables. The type of questionnaire used in this study's data collection is a structured questionnaire consisting of questions and statements with several specific answers as an option; the respondent chooses the answer that best suits his position.

\section{Data analysis process}

Data analysis is intended to examine the hypothesis. The data analysis technique used in this study is regression analysis, both simple regression and multiple regression. Before data analysis is carried out, a description of the research data consists of two independent variables and one dependent variable in frequency distribution tables and diagrams. The next step is to carry out the data analysis requirements test consisting of normality test, linearity test, and multicollinearity test. The hypothesis tested in this study is the influence of independent variables (X1 and X2) on the dependent variable (Y) both partially and simultaneously. To determine whether the independent variable $X$ influences the dependent variable $\mathrm{Y}$ is done by calculating the statistical test $\mathrm{F}$ value. The influence of the independent variables together on the dependent variable $\mathrm{Y}$ is done by calculating the value of the determination coefficient (R2). The magnitude of each independent variable's influence on the dependent variable is determined based on the statistical t-test (Purwanto, 2007: 193-194). Calculation of the F-test statistical values in this study uses the SPSS Statistics 24.

\section{Findings}

\section{Description of the object}

Cooperative Maju Makmur Sampetan is formed in November 2017 due to the Participatory Action Research program committed by Partono and the 
Smaratungga Buddhist College PAR Team. Cooperative Maju Makmur Sampetan which is located in Gumuk, Sampetan Village, Ampel District, Boyolali Regency. Cooperative Maju Makmur Sampetan has an incorporated legal institution called the Producer Cooperative Maju Makmur Sampetan, approved in the Decree of the Minister of Cooperatives and Small and Medium Enterprises Number: 008707/BH/M.KUKM.2/VI/2018. This decree was issued on June 5, 2018. Members of the cooperative currently number 77 people, consisting of 52 men and 25 women. Business units that are run are retail groceries, home industry ("Merbabu" bakery), and non-borrowed deposits.

\section{Instrument's validity and reliability}

The validity test of research instruments using product-moment correlation analysis with the help of the IBM SPSS Statistics 24 program shows that the participatory assistance variable statement items (14 items), organizational culture (22 items), and social capital ( 24 items) have a valid status. The reliability test results show that the research instrument for participatory assistance variables, organizational culture, and social capital is reliable because Cronbach's alpha value is more significant than 0.6. It shows that this research instrument fulfils the requirements to be a measuring instrument that can be used repeatedly.

\section{Descriptive analysis of variables}

Descriptive analysis of participatory assistance

Table 1. Frequency distribution of participatory assistance by category

\begin{tabular}{lllll} 
No. & Category & Interval & Frequency & Percentage \\
\hline 1. & Very Bad & $14-24$ & 0 & $0 \%$ \\
2. & Bad & $25-35$ & 0 & $0 \%$ \\
3. & Good Enough & $36-46$ & 8 & $10 \%$ \\
4. & Good & $47-57$ & 47 & $61 \%$ \\
5. & Very Good & $58-70$ & 22 & $29 \%$ \\
\hline & Total & & 77 & $100 \%$
\end{tabular}

(Source: research data)

Respondents' responses to participatory assistance showed an average score of 3.86 with good categories. Of the 77 respondents, 22 respondents said it was very good, 47 respondents said it was good, and 8 respondents said it was good enough. There were no bad and very bad responses to the participatory assistance variable. Respondent's response to the horizontal relationship sub variable showed an average score of 3.88 with good categories. The Sub variable of process prioritization showed an average score of 3.84 with good categories, and the sub variable of needs-based substances showed an average score of 3.84 with good category. 


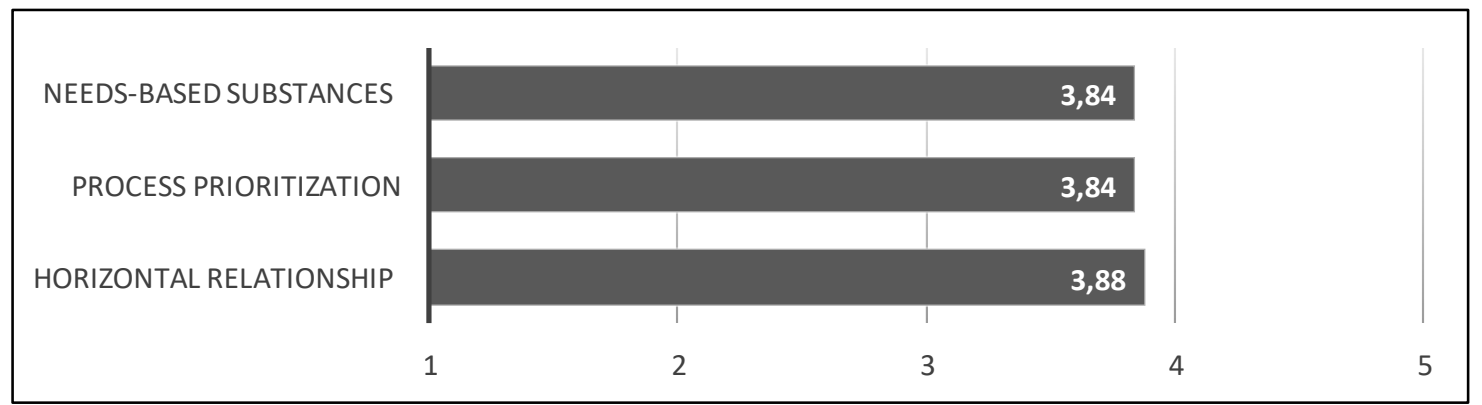

Figure 1. Average of participatory assistance's sub variables

\section{Descriptive analysis of organizational culture}

Respondents' responses to organizational culture showed an average score of 3.93 with good categories. Of the 77 respondents, 12 respondents said it was very good, 62 respondents said it was good, and three respondents said it was good. There are no bad and very bad responses to organizational culture variables.

Table 2. Frequency distribution of organizational culture by category

\begin{tabular}{lllll}
\hline No. & Category & Interval & Frequency & Percentage \\
\hline 1. & Very Bad & $22-39$ & 0 & $0 \%$ \\
2. & Bad & $40-57$ & 0 & $0 \%$ \\
3. & Good Enough & $58-75$ & 3 & $4 \%$ \\
4. & Good & $76-93$ & 62 & $81 \%$ \\
5. & Very Good & $94-110$ & 12 & $16 \%$ \\
\hline & Total & & 77 & $100 \%$
\end{tabular}

(Source: research data)

Respondent's responses to the sub variable of innovation and risk-taking showed an average score of 3.92 with good categories, sub variable of stability and security showed an average score of 3.93 with good categories, sub variable of appreciation to people showed an average score of 3.95 with good category, subvariable results orientation shows an average score of 3.93 with good categories, sub variable of team orientation and collaboration show an average score of 3.90 with good categories. Sub-variables of aggressiveness and competition show an average score of 3.93 in the good category. 


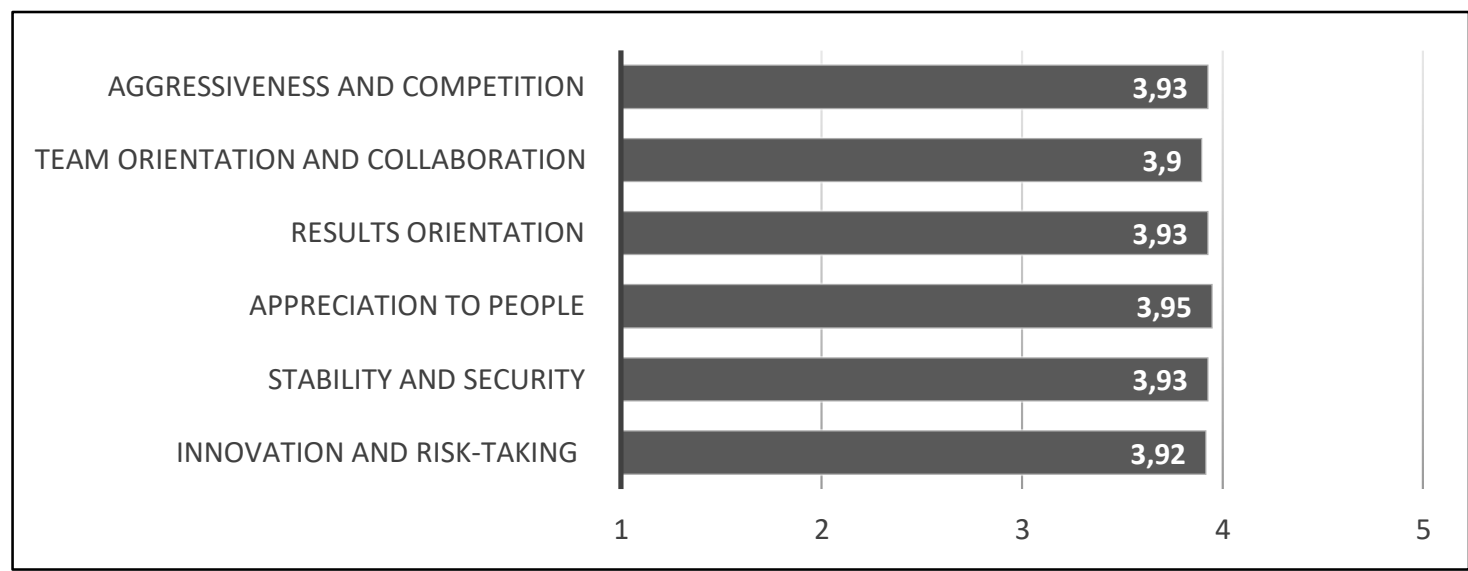

Figure 2. Average of organizational culture's sub variables

\section{Descriptive analysis of social capital}

Table 3. Frequency distribution of social capital by category

\begin{tabular}{lllll}
\hline No. & Category & Interval & Frequency & Percentage \\
\hline 1. & Very Bad & $24-42$ & 0 & $0 \%$ \\
2. & Bad & $43-61$ & 0 & $0 \%$ \\
3. & Good Enough & $62-80$ & 7 & $9 \%$ \\
4. & Good & $81-99$ & 47 & $61 \%$ \\
5. & Very Good & $100-120$ & 23 & $30 \%$ \\
\hline & Total & & 77 & $100 \%$
\end{tabular}

(Source: research data)

Respondents' responses to social capital showed an average score of 3.88 in the good category, as many as 23 respondents said it was very good, 47 respondents said it was good, and 7 respondents said it was good enough. There are no bad and very bad responses to the variables of social capital. Respondents' responses to the sub variable of trust showed an average score of 3.87 with good categories, sub variable of social networks an average score of 3.90 with good categories, and sub variable of norms showed an average score of 3.89 with categories well.

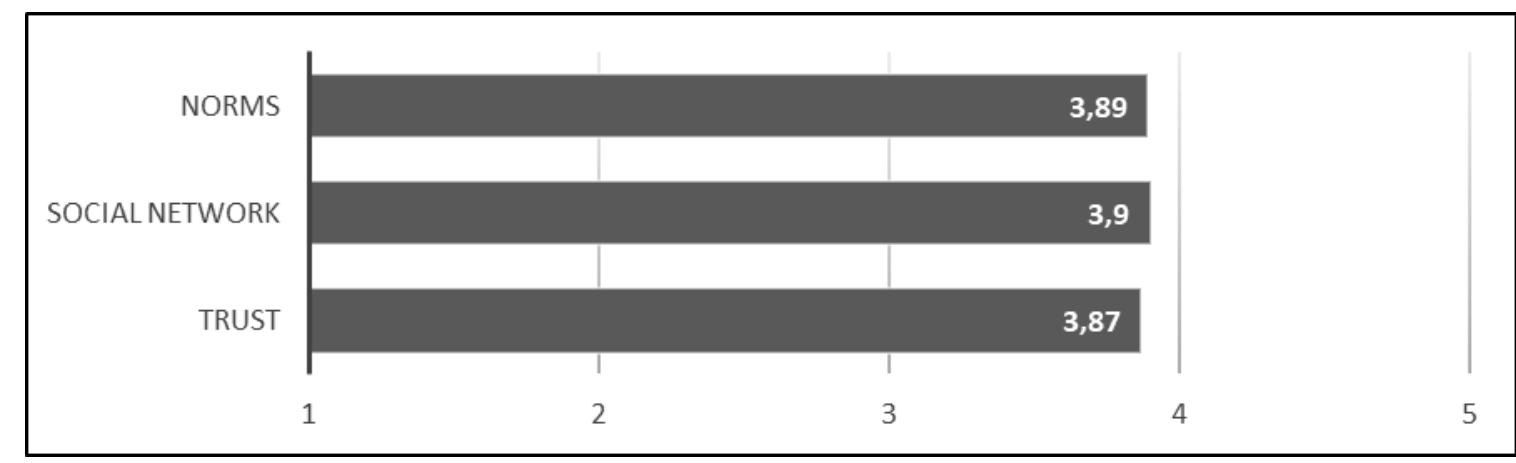

Figure 3. Average of social capital's sub variables 


\section{Requirement tests}

The normality test results showed that the data on participatory assistance, organizational culture, and social capital had a significant number of 0.200 . It shows that the data are typically distributed (Sig.> 0.05). Linearity test results show that all variables have a significance value smaller than 0.05 , so the research variable is linear. The multicollinearity test results show that the VIF value of the participatory assistance and organizational culture variables is 1.528 . It can be concluded that there is no multicollinearity in this research data. It means that the variables of participatory assistance (X1) and organizational culture (X2) does not interfere or influence each other.

\section{Regression analysis}

Table 4. Correlation value between X1 and Y

\begin{tabular}{lllll} 
Model & $\mathrm{R}$ & R Square & Adjusted R Square & $\begin{array}{l}\text { Std. Error of the } \\
\text { Estimate }\end{array}$ \\
\hline 1 & 0,804 & 0,646 & 0,642 & 5,499 \\
\hline
\end{tabular}

(Source: output SPSS Statistics 24)

Table 5. Regression coefficient between X1 and Y

\begin{tabular}{lcccccc}
\hline \multirow{2}{*}{ Model } & \multicolumn{2}{c}{$\begin{array}{c}\text { Unstandardized } \\
\text { Coefficients }\end{array}$} & \multicolumn{2}{c}{$\begin{array}{c}\text { Standardized } \\
\text { Coefficients }\end{array}$} & \multirow{2}{*}{ t } & Sig. \\
\cline { 2 - 5 } & $\mathrm{B}$ & Std. Error & Beta & & \\
\hline \multirow{2}{*}{1 (Constant) } & 15,427 & 6,664 & & 2,315 & 0,023 \\
\cline { 2 - 5 } Participatory assistance & 1,437 & 0,123 & 0,804 & 11,711 & 0,000 \\
\hline
\end{tabular}

(Source: output SPSS Statistics 24)

The correlation value (R) between the participatory assistance variables (X1) with the social capital variable (Y) is 0.804 . This value can be interpreted that the relationship between the two variables tested is in the very strong category. The $\mathrm{R}$ Square value or the coefficient of determination shows how well the regression model is formed by interacting with the independent and dependent variables. The determination coefficient value obtained is $64.6 \%$, so that it can be interpreted that the participatory assistance variable (X1) has a contribution of $64.6 \%$ influence on the social capital variable (Y). The calculation of simple regression coefficients shows that the constant coefficient value is 15.427 and the coefficient of the independent variable $(\mathrm{X})$ is 1.437 . So that the regression equation $\mathrm{Y}=15.427+1.437 \mathrm{X}$ is obtained.

Table 6. Correlation value between X2 and Y

\begin{tabular}{lllll}
\hline Model & $\mathrm{R}$ & R Square & Adjusted R Square & $\begin{array}{l}\text { Std. Error of the } \\
\text { Estimate }\end{array}$ \\
\hline 1 & 0,752 & 0,565 & 0,560 & 6,097 \\
\hline
\end{tabular}

(Source: output SPSS Statistics 24) 
Table 7. Regression coefficient between $\mathrm{X} 2$ and $\mathrm{Y}$

\begin{tabular}{|c|c|c|c|c|c|c|}
\hline & \multirow[t]{2}{*}{ Model } & \multicolumn{2}{|c|}{$\begin{array}{c}\text { Unstandardized } \\
\text { Coefficients } \\
\end{array}$} & \multirow{2}{*}{$\begin{array}{c}\begin{array}{c}\text { Standardized } \\
\text { Coefficients }\end{array} \\
\text { Beta }\end{array}$} & \multirow[t]{2}{*}{$\mathrm{t}$} & \multirow[t]{2}{*}{ Sig. } \\
\hline & & $B$ & Std. Error & & & \\
\hline \multirow{2}{*}{1} & (Constant) & 2,975 & 9,152 & & 0,325 & 0,746 \\
\hline & Organizational culture & 1,043 & 0,106 & 0,752 & 9,878 & 0,000 \\
\hline
\end{tabular}

(Source: output SPSS Statistics 24)

The correlation value (R) between the variables of organizational culture (X2) with the variable social capital (Y) is 0.752 . This value can be interpreted that the relationship between the two variables tested is in the very strong category. The determination coefficient value obtained is $64.6 \%$, so that it can be interpreted that the participatory assistance variable (X2) has a contribution of $56.5 \%$ influence on the variable social capital (Y). The regression analysis result shows that the constant coefficient value is 2.975 and the coefficient of the independent variable $(\mathrm{X})$ is 1.043. So that the regression equation $\mathrm{Y}=2.975+1.043 \mathrm{X}$ is obtained.

Table 8. Correlation value between X1, X2, and Y

\begin{tabular}{lllll} 
Model & $\mathrm{R}$ & R Square & Adjusted R Square & $\begin{array}{l}\text { Std. Error of the } \\
\text { Estimate }\end{array}$ \\
\hline 1 & 0,875 & 0,766 & 0,759 & 4,508 \\
\hline
\end{tabular}

(Source: output SPSS Statistics 24)

The correlation value (R) between the participatory assistance variable (X1) and the organizational culture variable (X2) on the social capital variable (Y) is 0.875 . This value can be interpreted that the relationship between the three variables tested is in the very strong category. The determination coefficient is 0.766 , so that it can be interpreted that participatory assistance and organizational culture contribute $76.6 \%$ to the strengthening of social capital. The regression analysis results show that the constant coefficient value is $-11,482$, the regression coefficient variable $\mathrm{X} 1$ is 0.989 , and the regression coefficient variable $\mathrm{X} 2$ is 0.592 . So that the regression equation $\mathrm{Y}=0.989 \mathrm{X} 1+0.592 \mathrm{X} 2-11.4882$ is obtained.

Table 9. Regression Coefficients between X1, X2, and Y

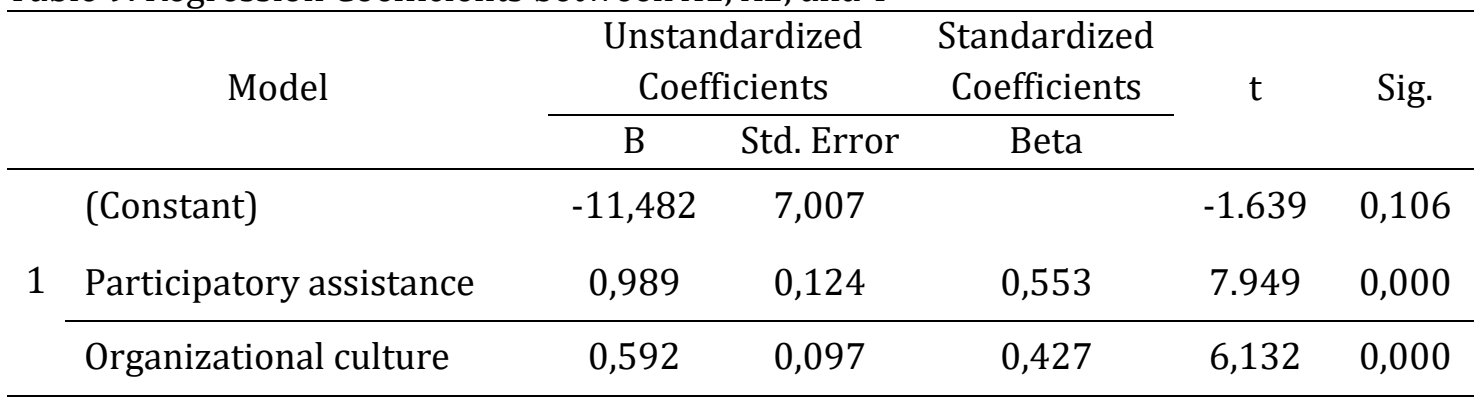

(Source: output SPSS Statistics 24) 


\section{Effective contribution and relative contribution analysis}

Table 10. Correlation and regression summary

\begin{tabular}{lllll}
\hline No & Variables & Beta & $\mathrm{R}$ & $\mathrm{R}^{2}$ \\
\hline 1. & Participatory assistance $\left(\mathrm{X}_{1}\right)$ & 0,553 & 0,804 & \multirow{2}{*}{0,766} \\
2. & Organizational culture $\left(\mathrm{X}_{2}\right)$ & 0,427 & 0,752 & \\
\hline
\end{tabular}

(Source: output SPSS Statistics 24)

The calculation of EC and RC of each variable shows that the participatory assistance variable has an effective contribution (EC) of $44.5 \%$ and relative contribution (RC) of 58\%, while the organizational culture variable has an effective contribution (EC) of $32.1 \%$ and relative contribution (RC) of $41.9 \%$. It shows that the participatory assistance variable contributes more to strengthening social capital than organizational culture variables.

\section{Correlation per sub variable analysis}

Table 11. Correlation value per sub variables $\mathrm{X} 1$ and $\mathrm{Y}$

\begin{tabular}{llllll}
\hline No. & $\mathrm{R}$ & $\mathrm{Y} 1$ & $\mathrm{Y} 2$ & $\mathrm{Y} 3$ & $\mathrm{Y}$ \\
\hline 1. & $\mathrm{X} 1.1$ & 0,828 & 0,473 & 0,723 & 0,920 \\
2. & $\mathrm{X} 1.2$ & 0,613 & 0,359 & 0,542 & 0,743 \\
3. & $\mathrm{X} 1.3$ & 0,615 & 0,359 & 0,597 & 0,760 \\
\hline & $\mathrm{X} 1$ & 0,854 & 0,494 & 0,772 & 0,804 \\
\hline
\end{tabular}

(Source: output SPSS Statistics 24)

The correlation coefficient variable $\mathrm{X} 1$ to sub variable $\mathrm{Y} 1$ is 0,854 . Sub variable X1.1 has the most significant correlation coefficient on the sub variable $Y 1$, which is 0.828 . The correlation coefficient variable X1 to sub variable Y2 is 0.494 . Sub variable X1.1 has the most significant correlation coefficient of sub variable Y2, which is equal to 0.473 . Variable correlation coefficient $\mathrm{X} 1$ to $\mathrm{Y} 3$ sub variable is 0.772 . Sub variable X1.1 has the most significant correlation coefficient on the sub variable $\mathrm{Y} 3$, which is 0.723 . The $\mathrm{X} 1.1$ sub variable has the strongest correlation to variable $Y$. it means the horizontal relationship most strengthen social capital. Correlation analysis of $\mathrm{X} 1$ variables on sub variable $\mathrm{Y} 1, \mathrm{Y} 2$, and $\mathrm{Y} 3$ shows that participatory assistance contributes most to strengthening trust.

Table 12. Correlation value per sub variables $\mathrm{X} 2$ and $\mathrm{Y}$

\begin{tabular}{llllll}
\hline No. & $\mathrm{R}$ & $\mathrm{Y} 1$ & $\mathrm{Y} 2$ & $\mathrm{Y} 3$ & $\mathrm{Y}$ \\
\hline 1. & $\mathrm{X} 2.1$ & 0,474 & 0,249 & 0,492 & 0,455 \\
2. & $\mathrm{X} 2.2$ & 0,715 & 0,574 & 0,682 & 0,733 \\
3. & $\mathrm{X} 2.3$ & 0,668 & 0,840 & 0,515 & 0,749 \\
4. & $\mathrm{X} 2.4$ & 0,059 & 0,048 & 0,014 & 0,050 \\
5. & $\mathrm{X} 2.5$ & 0,791 & 0,607 & 0,757 & 0,803 \\
6. & $\mathrm{X} 2.6$ & 0,517 & 0,208 & 0,542 & 0,477 \\
\hline & $\mathrm{X} 2$ & 0,746 & 0,565 & 0,703 & 0,752
\end{tabular}

(Source: output SPSS Statistics 24) 
The correlation coefficient variable $\mathrm{X} 2$ to sub variable $\mathrm{Y} 1$ is 0.746 . The $\mathrm{X} 2.5$ sub variable has the most significant correlation coefficient for the Y1 sub variable, 0.791 . The correlation coefficient variable $\mathrm{X} 2$ to sub variable $\mathrm{Y} 2$ is 0.565 . The $\mathrm{X} 2.3$ sub-variable has the most significant correlation coefficient on the sub-variable Y2, which is 0.840 . The correlation coefficient variable $\mathrm{X} 2$ to sub variable $\mathrm{Y} 3$ is 0.703 . The X2.5 sub variable has the most significant correlation coefficient for the Y3 sub variable, which is 0.757 . The $\mathrm{X} 2.5 \mathrm{sub}$ variable has the strongest correlation to variable $Y$. It means team orientation and collaboration most strengthen social capital. Correlation analysis of X2 variables on sub variable Y1, Y2, and Y3 shows that organizational culture contributes most to strengthening trust.

\section{Discussion}

\section{The influence of participatory assistance on strengthening social capital}

The first hypothesis test results show that the regression direction coefficient of the participatory assistance variable (B1) is 1.437 . It can be said that the participatory assistance variable has a positive effect on social capital. The significance test of multiple linear regression coefficients for participatory assistance variables (B1) shows $t$ count $(11,711)>t$ table $(1,665)$ and significant value $<0,05$ that is 0,000 with a relative contribution of $58 \%$ and effective contribution of $44,5 \%$.

The data analysis results show that the better participatory assistance, the stronger the social capital owned by Cooperatives. Participatory assistance that has been carried out in Buddhist community Cooperatives, especially in the Producers of Maju Makmur Sampetan Cooperative, has gone well by meeting the following criteria:

\section{Horizontal relationship}

The relationships that exist between facilitators and assistants are horizontal. The companion places himself as a facilitator and implements an adult education system. The closeness between the facilitators and the assistance shows that the participatory assistance process is going well. The companion, which included the STIAB Smaratungga Companion Team, the Boyolali District Cooperative Office, and Cooperative Maju, implemented a participatory assistance process by establishing horizontal relationships. Respondents' responses show this to horizontal relationships have an average of 3.88 in the good category.

\section{Process prioritizing}

Assistance focuses on the active role of assistance to participate in all activities, such as meetings, discussions and training. Assistance activities for members of the Cooperative have prioritized the process. The respondent's response shows this to the process, prioritizing having an average of 3.84 in the good category. 


\section{Needs-based substance}

Assistance and training materials are tailored to the needs of members. The skills developed are the use of surrounding natural resources and economic endeavours. The substance of assistance provided to cooperatives has been based on members' needs. Respondents' responses show this to need-based substances having an average of 3.84 with good categories.

\section{The influence of organizational culture on strengthening social capital}

The second hypothesis test results show that the regression direction coefficient of the organizational culture variable (B2) is 1,043, so that it can be said that organizational culture variables have a positive effect on social capital. The significance test of multiple linear regression coefficients for organizational culture variable (B2) shows $t_{\text {count }}(9,878)>t_{\text {table }}(1,665)$ and significant value $<0,05$ that is 0,000 with a relative contribution of $32,1 \%$ and effective contribution of $41,9 \%$.

The data analysis results show that the better the organizational culture, the stronger the social capital owned by Cooperatives. The organizational culture that has been formed in Buddhist community Cooperatives, especially in the Producers of Maju Makmur Sampetan Cooperative, has developed well by having the following characteristics:

\section{Innovation and risk-taking}

Cooperatives are always looking for new opportunities, dare to take risks, experiment, and do not feel constrained by formal policies and practices. Koperasi Maju Makmur Sampetan has good innovation and risk taking. It is evidenced by respondents' average response to innovation and risk-taking of 3.92 with good categories.

\section{Stability and security}

Cooperatives value predictable things, maintain security, and set rules that direct behaviour. Cooperative Maju Makmur Sampetan has good stability and security. The average respondent's response to stability and security of 3.93 is evidenced by the average respondent's response to a good category.

\section{Appreciating people}

Cooperatives must have tolerance, uphold justice, and have respect for others. Cooperative Maju Makmur Sampetan has appreciated well. It is evidenced by the average response of respondents to the award of 3.95 with good category.

\section{Result orientation}

Cooperatives must have excellent attention and expectations for results, achievements and actions. Cooperative Maju Makmur Sampetan has a good results orientation. It is evidenced by the average respondent's response to the results orientation of 3.93 with good categories. 


\section{Team orientation and collaboration}

Cooperatives must be able to work together in a coordinated and collaborative manner. Cooperative Maju Makmur Sampetan has good team orientation and collaboration. It is evidenced by the average respondent's response to team orientation and collaboration of 3.90 in the good category.

\section{Aggressiveness and competition}

Cooperatives must be able to take decisive actions in the face of competition. Cooperative Maju Makmur Sampetan already has aggressiveness and good competition. It is evidenced by the average respondent's response to aggressiveness and competition of 3.93 in the good category.

\section{The influence of participatory assistance and organizational culture on strengthening social capital}

The third hypothesis test results show that participatory assistance and organizational culture together influence social capital. It is indicated by the $\mathrm{F}_{\text {count }}$ value $(120.836)>t$ table $(3.15)$ with significance $(0.000)<0.05$. The determination coefficient is obtained at 0.766 , which means that the contribution of the influence given by participatory assistance and organizational culture together on strengthening social capital is $76.6 \%$.

The solid social capital possessed by the Producer Cooperative Maju Makmur Sampetan can be seen from the following elements:

Trust

Every member of the cooperative must have honesty, fairness, egalitarian attitude, tolerance and generosity. Members of the Maju Makmur Sampetan Cooperative have good trust. It is evidenced by the average response of respondents to trust of 3.87 with a good category.

\section{Social network}

The attitude that must be built between cooperatives and between groups is participation, reciprocity, solidarity, and cooperation. Members of the Maju Makmur Sampetan Cooperative have an excellent social network. It is evidenced by the average response of respondents to social networks by 3.90 with good categories.

\section{Norms}

Cooperative members must uphold shared values, norms and sanctions, and obey the rules. Members of the Maju Makmur Sampetan Cooperative have good norms. It is evidenced by the average respondent's response to the norm of 3.89 in the good category.

Participatory assistance and organizational culture influence the strengthening of social capital of Cooperatives of Buddhist communities by $76.6 \%$, so the remaining $23.4 \%$ is influenced by other variables not examined in this 
study. These variables can be in education level, level of welfare, motivation to participate in cooperative, and social environment.

\section{Conclusion}

This study aims to analyze the influence of participatory assistance and organizational culture on strengthening the social capital of Buddhist Cooperative, especially Cooperative Maju Makmur Sampetan. The main characteristic of participatory assistance is that the facilitator's relationship with participants is no longer vertical but horizontal, prioritizes the process rather than results, and the substance of the training material refers to participants' needs. A Cooperative's organizational culture can strengthen social capital because it contains innovation and risk-taking characteristics, stability and security, respect for people, results in orientation, team orientation and collaboration, and aggressiveness and competition.

Research on the effect of participatory assistance and organizational culture on strengthening social capital of Cooperatives in Buddhist communities has the following results: (1) participatory assistance has been carried out well shown by the average response to participatory assistance at 3.86 with a good category, (2) organizational culture is well developed which is indicated by the average response to organizational culture of 3.93 with good categories, (3) Strong social capital shown by the average response to social capital of 3.88 with a good category, (4) Participatory assistance has a positive effect on strengthening social capital which is indicated by the correlation coefficient of $0.804,(5)$ Organizational culture has a positive effect on strengthening social capital which is indicated by the correlation coefficient of 0.752 , and (6) Participatory assistance and organizational culture together have a positive effect on strengthening social capital with a contribution of $76.6 \%$. Participatory assistance contributed effectively to $44.5 \%$, while organizational culture contributed effectively to $32.1 \%$. It shows that participatory assistance contributes more to strengthening the social capital of Cooperatives in Buddhist communities. Therefore, based on the research finding, the suggest for next researchers is to be able to conduct intensive observations on the participatory assistance in order to strengthen the social capital of cooperative.

\section{References}

Boone, C. (2014). Why do cooperatives emerge in a world dominated by corporations? the diffusion of cooperatives in the U.S. bio-ethanol industry, 1978-2013. The Academy of Management Journal, 57, 990-1012. doi: 10.5465/amj.2012.0194.

Hubaib, F. (2020). Learning indicator of cooperative management in the review of the economic perspective. Jornal Ecodemica, 4(1), 85-91. Retrieved from: https://ejournal.bsi.ac.id/ejurnal/index.php/ecodemica/article/view/7578 /pdf.

Harvey, P. (2000). An Introduction to Buddhist Ethics. UK: Cambridge.

Hasbullah, J. (2006). Social Capital (Menuju Keunggulan Budaya Manusia. 
Indonesia). Jakarta: MR-United Press.

International Co-operation Alliance. (2015). Guidance notes to the Co-operative Principles.

Lawang, R.M.Z. (2004). Kapita Sosial Dalam Perspektif Sosiologi: Suatu Pengantar. Depok: FISIP UI Press.

Marhalim, I.I. (2015). Strategi Penguatan Modal Sosial Kelompok Swadaya Masyarakat (KSM) Pada Program Community Development PT. Newmont Nusa Tenggara. Tesis. Bogor: Institut Pertanian Bogor. Retrieved from: https://nanopdf.com/download/strategi-penguatan-modal-sosialkelompok_pdf.

Munandar, A.S. (2008). Psikologi Industri dan Organisasi. Jakarta: Universitas Indonesia.

Nadeak, B. (2016). Pengaruh budaya organisasi terhadap Organizational Citizenship Behavior (OCB) dosen di Universitas Kristen Indonesia (UKI). Jurnal Manajemen Pendidikan, 5(1). 1-10. Retrieved from: http://repository.uki.ac.id/id/eprint/1742.

Partono. (2017). Pemberdayaan Umat Buddha Melalui Program PAR Kelompok Swadaya Masyarakat (KSM) Vihara Mandiri Desa Sampetan, Kecamatan Ampel, Kabupaten Boyolali Tahun 2017. Boyolali: STIAB Smaratungga

Sivaraksa, S. (2013). Pembangunan Untuk Manusia (Ekonomi Buddhis Abad Ke21). Terjemahan. Jakarta: HIKMAHBUDI

Sobirin, A. (2019). Budaya Organisasi: Pengertian, Makna dan Aplikasinya dalam Kehidupan Organisasi. Yogyakarta: UPP, STIM YKPN

Somba, A.B. (2017). Pengaruh Budaya Organisasi terhadap Solidaritas Sosial Pegawai (Studi Komparatif pada Pegawai PT. Bank Mandiri (Persero) Tbk Prioritas Outlet Perintis Kemerdekaan dan Non Prioritas Cabang Medan Perintis Kemerdekaan). Tesis. Medan: Universitas Sumatera Utara

Sugiyono. (2013). Metode Penelitian Pendidikan: Pendekatan Kuantitatif Kualitatif dan R\&D. Bandung: Alfabeta

Sukardi. (2003). Metodologi Penelitian Pendidikan Kompetensi dan Praktiknya. Jakarta: Bumi Aksara

Sutanto, J. (2009). The Dance of Change: Menemukan Kearifan Melalui Kisah-kisah Kebijaksanaan Timur. Jakarta: PT Gramedia

Tim Penyusun. 2007. Teknik Fasilitasi Partisipatif Pendampingan Masyarakat. Jakarta: Bappenas-UNDP.

Tremblay, E., Hupper, A., \& Waring, T.M. (2019). Co-opertive exhibit greater behavioral cooperation than comparablebusinesses: Experimental evidence. Journal of Co-operative Organization and Management, 7, 1-7. doi: 0.1016/j.jcom.2019.100092.

Wijayaratna, M. (1990). Buddhist Monastic Life. USA: Cambridge University

Wilcoxon, L. and Bruce, M. (2000). The management of organizational culture. Australian Journal of Management \& Organizational, 3(2), 91-99. Retrieved from:

https://citeseerx.ist.psu.edu/viewdoc/download?doi=10.1.1.468.9034\&rep $=$ rep $1 \&$ type=pdf. 